\title{
Existing Problems and Countermeasures on Cultivation of Applied Japanese Talents
}

\author{
Yanjun Liu \\ Liaoning Institute of Science and Engineering, Jinzhou, 121013, China \\ piaomia00411@126.com
}

Keywords: applied Japanese talents; cultivation; problems; countermeasures

\begin{abstract}
With the accelerating process of economic globalization and economic exchanges between China and Japan is increasingly close, proposed the new challenge to talents training in Japanese. With solid Japanese language foundation knowledge, master in the field of professional knowledge and skills, has the solidarity and cooperation spirit, bears hardships and stands hard work spirit, communication, communication ability, independent thinking ability and autonomous learning ability of applied Japanese talents is the need of talent. In order to improve the quality of the cultivation of the applied talents training in Japanese, has carried on the thorough investigation and study, analyzes the problems of applied talent training in Japanese, advances some countermeasures for the cultivation of applied Japanese talents, to deepen the reform of the Japanese teaching and train high quality applied Japanese talent service.
\end{abstract}

\section{Introduction}

Applied talents is to apply professional knowledge and skills in a specialized personnel engaged in professional social practice type, mastering a line of social production and social activities of basic knowledge and basic skills, is mainly engaged in production technology or a line of professional talents. With highly open international economy and trade, with the accelerating process of economic globalization and increasingly close economic exchanges between China and Japan, the Japanese talent cultivation put forward new requirements and challenges. Showed a trend of diversification and demand for foreign language talents in the past that a single foreign language professional and basic skills, already could not adapt to the demand of market economy, market demand on graduates who major in simple language and literature is gradually reduced, need to be able to meet the market demand, strong practical ability, high comprehensive quality of applied talents in Japanese.

Applied Japanese talents, need to know about Japanese culture, understand the business environment of the Japanese language habits and culture, have a good command of office software and Japanese business scene ability to engage in business activities, at the same time have the correct outlook on life and values, has the independent learning ability, team cooperation ability, communication ability and innovation ability, etc. the comprehensive quality of applied talents. Employment ability is an important index, including the ability to find work, maintain the employment ability and the ability to get a new job. In order to adapt to new requirements and the national economic and social development of higher education in the new situation, the need of applied talents training in Japanese studies, social needs, professional characteristics, and combining students' personalized development and to determine the training objectives, to develop more perfect reasonable talent training scheme [1]. Through in-depth investigation and study, analysis of applied Japanese problems of talent training, put forward the strategy of applied talent training in Japanese, to deepen teaching reform and train high quality applied Japanese talent service.

\section{Existing Problems on Cultivation of Applied Japanese Talents}

Rapidly developed Japanese majors of colleges and universities, which in the personnel training mode and curriculum setting is not perfect. In both direction of Japanese language and literature, 
"Japanese + characteristics" or bilingual mode, in the face of the rapid development of social economy, under the background of global integration industry, the fusion between Japanese talents and the contradiction between the demand of the Labour market. In the end, this kind of contradiction is the issue of talent cultivation. Current problems of applied talent training in Japanese summarized as follows:

(1) It is difficult to adapt to the new job requirements. Economic globalization development, among the various fields of mutual penetration unit of choosing and employ persons the demand for interdisciplinary talents has greatly increased. Most colleges and universities is suitable for the training of specialists in the field of Japanese engaged in teaching and scientific research as well as translation. But in Japanese-owned processing factories, foreign trade enterprise and mainly open to foreign customers, in the company to use Japanese also involves professional knowledge related to production, including information technology, machinery, finance, law, economics and management expertise and knowledge. Therefore, the actual Japanese did not achieve very good cohesion between talent training and employment.

(2) Lack of applied Japanese talent training facilities [2]. Most of the college attaches great importance to the development in science and engineering, liberal arts major lack of policy support and prize money. Japanese practice teaching funds investment co., LTD., a lot of colleges and universities are no independent Japanese training rooms, Japanese training facilities are attached to English majors, led to the Japanese training teaching become a mere formality. Most of off-campus practice base has nothing to do with the Japanese, part of the practice base is the hotel service industry, and Japanese practical application ability of students could not get exercise. Although some practice base is the company's enterprise, but enterprise in pursuit of maximum benefit as goal, considering the safety, production and management, and many other factors, is not willing to provide students with practical applied jobs, students cannot participate in the production practice.

(3) The course system is not suitable for applied talents training in Japanese [3]. In terms of curriculum system construction, the traditional Japanese talent training model to focus on language knowledge, but ignored the application of language, from the curriculum to the teaching methods and training mode tend towards research. So long time, the Japanese will tend towards Japanese curriculum system construction as knowledge to teach, not Japanese, as a kind of skills training, and course of practicality is not strong. Curriculum system is not reasonable often appear students language ability training and learning new skills in curriculum arrangement and teaching arrangement contradiction, if the curriculum is too dense, students will appear because of class hour quantity is too large, struggling to cope with the situation.

(4) The teachers strength is insufficient affects the quality of personnel training. The teacher is teaching activities, teachers' comprehensive quality and level of teaching effect plays an important role. The result of the enrollment expansion of colleges and universities is the insufficiency of teachers. Most Japanese senior titles of university teachers are usually only for professional backbone course, application classes is given priority to with the youth group, young teachers have their own advantages, but there are obvious in the experience in teaching and research level, knowledge of Japanese language system and grasp the association between knowledge, understanding of the level of the difficult and the students to master of teaching and management of the students in the class.

\section{Countermeasures on Cultivation of Applied Japanese Talents}

Aiming at the existing problem of applied talent training in Japanese, on the basis of analyzing the survey results, [4-9] with reference to previous research results, and puts forward some countermeasures of applied talent training in Japanese is as follows:

(1) The optimization of practice teachers, improving the "double division type". "Double type" teachers is to point to have a combination of teachers' qualifications and professional qualification, which requires specialized course teachers have the quality and ability of two aspects: one is that similar academic teachers, have higher cultural and professional theoretical level, has the strong ability and quality of teaching, research and teaching;2 to similar engineering and technical 
personnel, with broad basic specialized knowledge, skilled professional practice skills, certain ability to organize production management and technology promotion, and guide students' entrepreneurial ability and quality. Implementation of applied Japanese talent training, teacher training for practice teaching is the fundamental, is a powerful guarantee to improve training level and quality. Training and the introduction of "double type" teachers, exploring the co-operative resources, make full use of the enterprise's teacher to the student to carry on the practice teaching and guidance. Train applied talents, Japanese need practical operation experience, proficient in Japanese, "double type" teachers, such talent can be introduced from the enterprise, also can arrange teachers out of the campus to exercise social or business, or through the take up some training, supplement the basis of natural science and social science knowledge.

(2) Establish a scientific system of courses, curriculum building professional characteristics. Different curriculum system means the same professional course categories according to the order of production, is the sum of the teaching content and processes, order determines the kinds of students through learning how to obtain the knowledge structure. In order to satisfy the need of applied talents training in Japanese, it must be the organic combination of jobs and course content, promote Japanese professional personnel training mode innovation and diversified development. Closely around applied Japanese talents training course system, course content and post together, focus on professional front dynamic changes and related skills. In order to make clear the professional ability and individual ability as the standard, the implementation of the curriculum system, reasonable arrangement of progressive course content, to implement "living module, more direction" choice, reduce time of classroom teaching, to strengthen the autonomous learning and flexible module teaching. Set business Japanese translation and application of such direction, stimulate students' curiosity, exploit the potential of acquiring knowledge and sustainable development ability. Specialty courses, mainly refers to reflect the state and society demand development direction, can not only reflect the target of profession fostering, and can reflect the professional characteristics, in the national professional "man without I have, people have my superior" courses. Specialty courses can be either compulsory course, also can be elective courses, can change along with the market demand and adjust professional training requirements. Professional development courses at the same time, mainly according to the national and social development needs, on the basis of the existing professional courses, to broaden students' horizons, broaden the students' professional knowledge and skills, expanding employment and set the course.

(3) Application-oriented training objectives, clear training specifications. Comprehensive analysis of Japanese professional talent training of internal and external environment, as well as the main feature of applied talents and applied talents training in Japanese has three characteristics: first, is engaged in the related to Japanese first-line technical and management personnel; Second, Japanese language ability, culture ability and communication ability to cultivate more and more be taken seriously; Three is, practice teaching in applied Japanese talent training plays an important role in the process. Of applied Japanese talents training target description is as follows: with a broad basic knowledge, a solid knowledge of Japanese language and culture, fluent in listening, speaking, reading, writing and translating basic skills, such as strong ability of post practices and intercultural communication ability, can in the economic, trade, tourism and culture department, engaged in the work of translation, research and management, and other senior specialized talents. Applied talents cultivation specifications must follow the basic moderately, attaches great importance to the application and to strengthen the quality requirements, specific requirements are as follows: the knowledge structure, to adapt to the economic, trade, tourism and culture, etc., to two or more things industry compound and interdisciplinary characteristics, pay attention to the compound and application of knowledge. Already has a solid knowledge of Japanese language, also has the rich cultural knowledge, and the corresponding line to knowledge; Second, ability structure, should be to foster industry oriented practice ability and the ability to cross-cultural communication as the key point, mainly reflected in the ability of language and culture two aspects; Three is that quality structure, should have strong ability of society, including the ability of language expression, 
expression ability, team spirit and coordination ability, communication ability, and consider a problem carefully, etc.

(4) Strengthen the practical resource input, introducing social forces of running a school. Complete practice teaching environment is the important guarantee to realize students' practical ability, belongs to the category of liberal arts in Japanese major to cultivate effect is obvious science technology, combined with the recruitment of students scale is limited, the equipped with not enough focus on practical conditions in colleges and universities, which requires colleges to raise funds through various channels, increase investment in training of laboratory and practice base construction, not only need to increase school internal practice teaching base construction, and should open the door, go the way of cooperation between colleges and combining study, the off-campus practice base planning and selection, forming perfect internship practice base group, improve the students' practical ability and innovation ability, enhance students' social sense of responsibility and service consciousness. In addition, you can invite the enterprises and institutions of professional technical backbone personnel as a part-time teacher, the teaching of practical stronger course to improve students' language competence. Also needs to be built on the basis of the laboratory of the school training base, including the Japanese autonomous learning platform and business practice room, etc., to carry out the Japanese business skill integrated training and self-study, comprehensive language skills training of relying on the second classroom, and formulate detailed implementation plan.

(5) Improving teaching methods, implement diversification means. Teaching methodology is made up of the guiding ideology, basic methods, specific methods and teaching methods, etc. Including teachers' teaching methods and students learning method, is the unity of teaching method and learning method. Teaching methods to serve the teaching purpose and teaching to the task, is a common to complete the means of teaching activities, teachers and students both sides is teachers teaching activity the behavior of the system. According to the characteristics of applied talent training in Japanese, to adopt diversified teaching methods. Applied Japanese talents should have both cultural knowledge and language knowledge, also should have ability of language and culture. This requires that Japanese teachers in the teaching process according to their aptitude, develop the students' learning enthusiasm and all kinds of ability. Need to establish take the student as the main body of the guiding ideology, to conduct a comprehensive reform of classroom teaching. To conform to the student age characteristics and personality traits and characteristics of the teaching method of thinking, the boring and easy to accept the Japanese knowledge into image content; Understand the students' interest, give priority to in order to stimulate interest, rather than full lectures. The teacher in the teaching materials on the basis of fully research, more earnestly practice in class. On the basis of the teaching content, adhere to the situational teaching in the process of teaching and flexible and varied teaching methods such as case teaching. Actively adopt modern teaching means, the use of multimedia teaching, through introducing images such as intuitive and vivid teaching methods, arrange students to watch the Japanese anime and movies, etc., let the student to experience the life and culture, better learning Japanese and read Japanese and mastery of Japanese.

(6) Make full use of network resources, and strengthen the construction of teaching material. Training applied talents to adapt to the era development, which must choose practicality and advancement of the teaching materials to meet the basic requirements. Traditional teaching attach great importance to the grammar, ignoring the content is practical, some words have to keep up with the pace of The Times development, and widespread, the old content, the practical problems such as low consume fewer and new information. Therefore, we need to choose the latest materials, at the same time fusion of various materials, selectively for teaching. Vocabulary, with the development of economic and cultural exchanges, every year to produce a large number of new Japanese vocabulary, teachers should focus on the latest trend, through the network constantly added new information and new knowledge, and the appropriate import into classroom teaching. As a result of the new textbook editing publishing has certain periodicity, even if there are new materials to use limitations. The outdated information indiscriminately teaching affects education is practical. 
Therefore, the teacher will change according to the reality, the use of network information, update and communicate to the students. Teachers can also keep the teaching process of data written to adapt to the requirements of the textbooks, and in a timely manner through the teaching, to ensure that the teaching content of the past have diagnostic, guide me to reality, has the foresight for the future. At the same time, in order to have targeted for enterprise services, you can contact with unit of choose and employ persons, ordering cultivation, in the teaching process to import enterprise training plan, or hire experts to conduct joint training class directly.

\section{Conclusion}

Cultivation of employment ability of applied Japanese talents, students are required to have the solid basic knowledge of Japanese language and "listening, speaking, reading, writing and translation" and so on comprehensive language using ability, grasp a foreign professional knowledge and skills, with unity and cooperation and bear hardships and stand hard work spirit, communication, communication ability, independent thinking ability and autonomous learning ability, and a high degree of social responsibility. This article research results for applied talents training goal of guiding role in Japanese. But applied Japanese talent training is a complicated system engineering, a long-term task to improve students' application ability, needs to deepen teaching reform, need the department in charge of education, the joint efforts of schools, teachers and students. In the process of the practical training to strengthen the guide of students, teaching design, centering on the students give full play to students' subjective initiative, qualified applied Japanese talents to the society.

\section{References}

[1] Y. Yuan, "On the Application - Oriented Japanese Talents' Cultivation," Journal of Nanchang Normal University, vol. 35, no. 5, pp. 98-100, 2014.

[2] Z. L. Cai, "Applied Japanese language talents training strategies under the background of transformation development local colleges and universities," Journal of Changjiang Institute of Technology, vol. 33, no. 4, pp. 39-41, 2016.

[3] Q. J. Chen, "Problems and Countermeasures in the cultivation of applied talents of Japanese majors in Independent Colleges," Journal of Lanzhou Institute of Education, vol. 28, no. 8, pp. 7-8, 2016.

[4] Y. Qin, C. M. Zhang, "Innovation and practice of the training mode of Japanese talents in Applied Undergraduate Universities: A case study of Japanese majors in Dalian National University," Journal of Dalian Minzu University, vol. 18, no. 4, pp. 421-424, 2016.

[5] C. Q. Shen, "A Review of the curriculum system of talents training based on advanced Japanese applied technology" Journal of Hubei Correspondence University, vol. 29, no. 22, pp. 101-102, 2016.

[6] Y. S. Zhu, "Meet the needs of the society, Improve the competitiveness of employment: On the cultivation of Applied Talents in Japanese" Journal of Liaoning Higher Vocational, vol. 12, no. 9, pp. 11-12, 2010.

[7] L. J. Lu, "On the Reform of Japanese Curriculum of 'Applied Talents raining Mode In Transition Period'," Journal of Dalian University, vol. 37, no. 1, pp. 130-133, 2016.

[8] F. Zhao, "Analysis of Japanese teaching based on the cultivation of Applied Talents," Education Modernization, vol. 3, no. 20, pp. 5-6, 2016

[9] X. Y. Li, "The reform of Japanese teaching from the perspective of applied talents training mode," Journal of Language and Literature Studies, vol. 33, no. 17, pp. 116-117, 2013. 